\title{
MAY 24, 1968 AT INANGAHUA JUNCTION
}

\author{
T. Hogue*
}

The twin communities of Inangahua Camp and Inangahua Junction were rudely awakened at approximately $5.25 \mathrm{a}_{\circ} \mathrm{m}$. by a severe earthqualie. About a minute before the 'ciuake all the birdlife suddenly stopped their noisy calling and an uncanny stillness settled over the area. The first movement of the earthqualie was an upward displacement although a few argue that the initial displacement was to the north esst. No longer than two seconds later the high frequency vibrating and confusion of noise enveloped the town, then came the jolting of no discriminate pattern as shock-waves started to rebound through the region. During the peak of the earthquake most people who were by now fully awakened thought that "this was the end", any dissenters from this view acknowledged that it was "at least a beaut".

As the shocked and somewhat bewildered people gathered at the M.O.W. yard where a relief centre had been set up an overall picture began to talke shape of a situation few expected to see or experience。

All could tell of miraculous escapes from injury, though a few had suffered minor bruising and cuts。

With all roads impassable and the four domestic services of water, electricity, sewerage and telephone non-functional a general feeling of isolation pervaded "the camp".

The $6.30 \mathrm{NZBC}$ radio news, stating that mild earth tremors had been felt between luriwai and Timaru, made us aware that no one lnew of our plight. This prompted us to organise our community to spend an indefinite period in the shattered township。

Once the catering facilities were operating over open fires in the M.O.W. yard, and the search 2 work parties had been dispatched to check on outlying areas, attention could be paid to contacting the "outside world" by M.O.H. radio. Atmospheric conditions hampered this and it was not until $9.00 \mathrm{a}, \mathrm{m}_{0}$ that Gisborne $\mathrm{M}_{0} \mathrm{O}, \mathrm{W}$. heard the emergency call and provided a relay link with Vestport. Once direct contact with iestport had been estrblished the "salvage operation" leading up to final evacuation sathered impetus.

While the tornship was being checked to find suitable houses to act as dormitories if evacuation was not feasible or completed on the first day several interesting facts were noted: these were as follows:-

(a) That there was no greater loss of life or injury which could be attributed to the fact that most people, probably $95 \%$ of those in the area, were in bed when the initial displacement took place。

(b) The least damaced buildings were on continuous strip footings, the most damaged on decared wooden piles.

(c) Brick chinneys situated in the structure caused severe damage to houses, especially those with tile roofing。

+ Overseer, Hinistry of forlis (H.o.i.) Inangainua Canp. 
(d) Kitchens were potential deathtraps in an earthquake, more so than any other room in the house。

(e) Reinforced concrete block chimneys did not collapse during the quake, as did the brick ones.

(f) Fire would have finished off what the quake started had the quake occurred during daylight hours. This suggests a need for alternative community fire fighting equipment (other than water which failed)。

(g) Tal1 upright furniture, including bunks, crashed to the floor。 In my own home the only exceptions were a writing desk and a clothes drier, both against eastern walls.

(h) Large glass windows shattered.

(i) In my own house the only windows broken were in the west wall.

(j) A number of articles were later found to be jammed beneath skirting boards of houseso These included a rifle, a slipper, a framed picture and in one case 14 playing cards caught between a fire surround and the floor.

(k) Broken glass everywhere especially in kitchens from broken preserving bottles。

(1) The distance travelled by furniture \& chattels during the main tremor. 